\title{
Trade Openness and Economic Growth in Indonesia
}

\author{
Khoirul Ifa, Moh. Yahdi \\ Departement of Accounting, STIE Widya Gama Lumajang \\ Email:khoirul.ifa@gmail.com
}

\section{A R T ICLE INFO}

Date of entry:

07 July 2020

Revision Date:

23 August 2020

Date Received:

15 September 2020

\begin{abstract}
A B S T R A C T
Economic growth and international trade are related to one another. International trade stimulates long-term economic growth. The more trade activities in a country, the more rapid economic growth; this trade is a key component of development in a country, its contribution is felt with the increasing economic growth in several countries. The purpose of this study looks at the impact of trade openness on economic growth in Indonesia in 1986-2017. This research is a quantitative study using time series data from 19862017, research data obtained from the world bank, data analysis techniques using the GMM method to see the impact of trade openness on economic growth. The test results using the Generalized Method of Moments analysis method show that all variables significantly influence the dynamics of economic growth in Indonesia. This result is proven by the t-statistic probability value, which shows a smaller value compared to the t-table value. Then the value also has a probability of less than $\alpha$. It can be concluded that the variables of trade, FDI, inflation, and the number of workers have a significant effect on economic growth in Indonesia.
\end{abstract}

Keywords: Trade Openness, Economic Growth, GMM Indonesia. Wiga : Jurnal Penelitian Imu Ekonomi, 10(2), 163-170. https://doi.org/10.30741/wiga.v10i2.599

\section{INTRODUCTION}

Each country has the advantage of having trade openness, namely gaining wide market access, achieving high efficiency and economic competitiveness in each country, and getting great opportunities for employment. Meanwhile, openness in the financial sector can encourage the entry of foreign capital (capital inflow) and accelerate the accumulation of capital and technology transfer (Salvatore, 1997).

Economic growth is defined as an increase in national income usually offset by an increase in GDP; Arsyad (2010) states economic growth is defined as an increase in GDP or GNP regardless of whether the increase is greater or smaller than the rate of population growth, and whether there is a change in the economic structure or improvement institutional system or not. 
Economic growth and international trade are related to one another; international trade stimulates long-term economic growth. The more trade activities in a country, the more rapid economic growth; this trade is a key component of development in a country, its contribution is felt with the increasing economic growth in several countries. But what about the country of Indonesia? There are different treatments for the country of Indonesia. As a developing country, Indonesia is a country with a fairly stable export value, as evidenced from 2017-2018, export growth rose by $10 \%$, with a stable import value (Statistics Indonesia, 2019). The assumption of positive exports and stable imports in Indonesia shows the level of trade openness in Indonesia has an impact on the economy, especially economic growth, in terms of GDP.

The relationship between economic growth theory and trade can be explained using Adam Smith's absolute advantage theory in 1776 and David Ricardo's comparative advantage theory in 1817 (Salvatore, 1997). Absolute advantage theory states that if a country produces commodities more efficiently than other countries and is less efficient in producing other commodities than other countries, the two countries can specialize in products by exchanging commodities that have an absolute advantage with commodities that have absolute losses.

While the comparative advantage theory states that although a country is less efficient in producing a commodity compared to other countries, it means that the country has no absolute advantage, but the two countries can still make a profitable trade, the theory put forward by David Ricardo also mentions that trade can occur between countries if there are comparative advantages, comparative advantages will be achieved if a country is able to produce goods and services that are more expensive and cheaper than other countries.

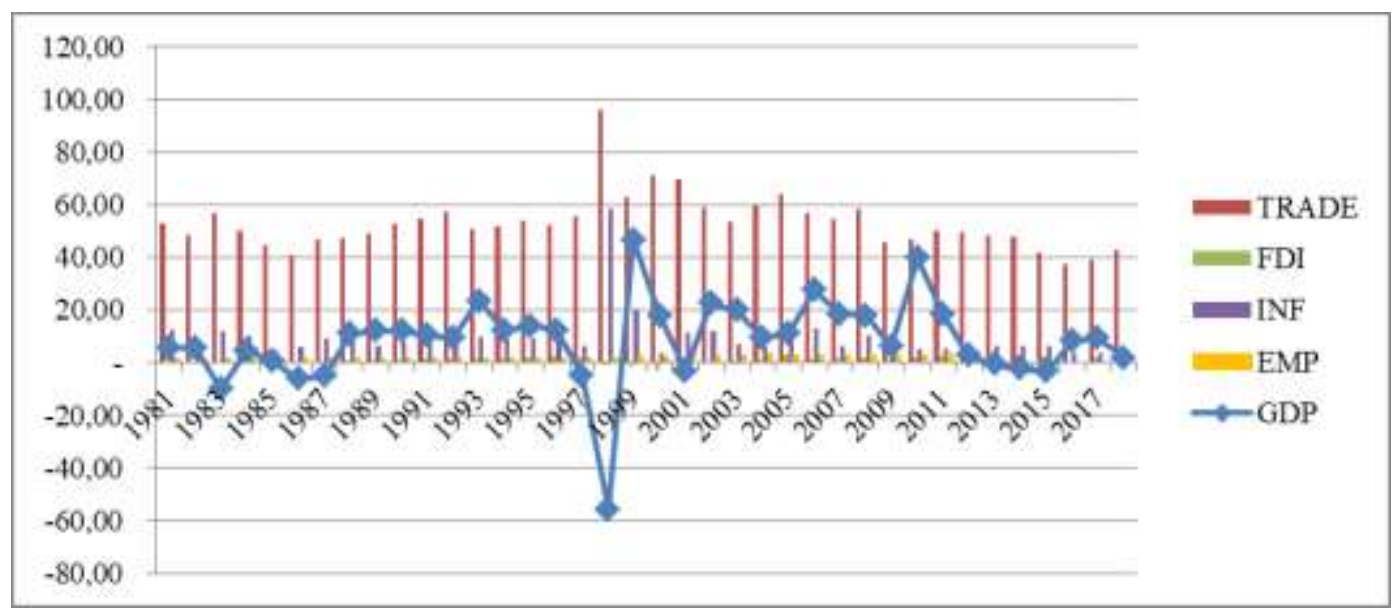

Source: World Bank, 2019

Figure 1. GDP, TRADE, FDI, Inflation, and Employment

The measurement of trade openness uses the ratio of exports plus imports to GDP. The development of trade openness in Indonesia shows quite fantastic developments; this can be seen from 1981-1997. At its peak in 1998, Indonesia's trade openness showed a figure of $96.19 \%$, far above the value of economic growth, which at that time fell to the level of $-0.25 \%$; this is suspected at that time was the Asian Financial Crisis. At that time, the value of the rupiah currency depreciated greatly so that the export price of Indonesian manufacturing was world average; in other words, Indonesian manufactured products did not yet have a comparative advantage. In fact, the Indonesian manufacturing sector has enormous potential, considering the many sectors that can still be developed as proven by having been in the growth stage (increasing exports). At that time, the value of the rupiah currency depreciated so much that the price of Indonesian manufactured exports was very low on the world market, thus increasing demand for exports. In line with the 
improvement in domestic economic conditions, the percentage of trade openness continued to decline until the 2014-2015 period was quite low, ranging from 41 percent; this shows that the intensity of Indonesia's trade was not too large, also supported by a slowdown in the world economy which reduced demand for manufactured exports from Indonesia.

International trade is believed to be one of the catalysts of productivity and economic growth, and its contribution is very calculated in economic activities. Countries that are active internationally tend to be more productive than countries that only produce for local markets. In addition, international trade promotes the efficient allocation of resources and can lead to higher levels. Economic growth is also associated with the spread of technology and the dissemination of knowledge (Vehapi, Sadiku, and Petkovski, 2015).

There are some differences in perception between the relationship between trade openness and economic growth; there is a positive relationship between trade openness and economic growth (Frankel and Romer, 1999). Sachs and Warner, 1995 believes open countries show higher growth rates than protectionist countries, further Dollar and Kraay (2004) explain that large trade openness will increase economic growth,

Pradhan 2017 et al. mentioned that there is a long-term relationship between trade openness, depth of the banking sector, and economic growth, but the nature of the causal relationship is complex, further pradhan, 2017, promote free trade policies. Vehapi, Sadiku, and Petkovski, 2015 stated trade openness encouraging the growth of countries with higher GDP per capita (or rich countries), trade openness will benefit countries with higher gross fixed capital formation and countries with higher FDI.

Research by Chen and Gupta (2006) and Chang et al. (2009) note that the positive impact of trade openness on economic growth is determined by the conditions and improvements made by each country on other factors as support. Bojanic, 2012 shows that there is a long-term balance in the relationship between economic growth, financial development, and trade openness. Furthermore, the results of Granger's causality were found to be related to financial indicators, indicators of development, and trade openness to economic growth.

Kyophilavong et al. (2015) stated that encouraging trade openness, economic growth, and feedback will encourage energy consumption. Shahbaz et al. (2016) argue that trade openness reduces carbon emissions in most countries. Trade openness causes CO2 emissions for high and low-income countries in the long run.

Chen and Gupta (2006) and Chang et al. (2009) mentions that there are several factors supporting economic growth and global trade performance, namely the presence of foreign investment (PMA), financial sector readiness (financial system), economic stability and prices, public infrastructure, quality of human capital, technological progress, and employment.

Based on the above problems, the problem of this research is how the impact of trade openness on economic growth in Indonesia?. The hypotheses in this research are in accordance with those developed in theoretical and empirical studies as follows: 1. Trade openness has a positive impact on economic growth in Indonesia. 2. The impact of trade openness on economic growth will increase/decrease when followed by an increase/decrease in inflation, foreign investment (FDI), education level, and the number of workers 


\section{METHOD}

This research is quantitative research. Quantitative research is research by looking at numerical data, then tested statistically. The purpose of this study is explanatory (explanatory research), where explanatory research is a type of research that explains the causal relationship between one variable with other variables through hypothesis testing. The object of this study in Indonesia by looking at the impact of trade openness on economic growth. Data collection techniques using documentation studies by collecting secondary data, taking notes, and processing data related to this research. According to Azwar (2001: 91), Secondary data is usually in the form of documentation data or report data that has been available. The data used include Trade Openness, inflation, foreign investment (FDI), education level, and the number of workers, and Economic Growth (GDP). While the type of data used is the 1986-2017 time-series data. Sources of data obtained from the World Bank.

Then the specification of this research model is written in equation 1, as follows: 1) $g d p=f($ tradeopenness, $F D I, \operatorname{Inf}$, Empty) . Where the model is then transformed into the econometrics model as follows: 2) $g d p_{t}=\beta_{0}+\beta_{1} T_{\text {rade }}+\beta_{2} F D I_{t}+\beta_{3} i n f_{\mathrm{r}}+\beta_{4} e m p l l_{t}+\varepsilon_{t}$. Where: $g d p_{t}=$ Economic Growth $(\%)$ in period t. Trade $_{t}=$ Trade Openness $(\%)$ in period t. $F D I_{t}=$ Total incoming FDI $(\%)$ in period t. ${ }^{e m p l y} y_{t}=$ Total Number of Workers (\% Total Population) in period t. $\beta=$ Coefficient. $\varepsilon=$ Error term. Equation 2 is then transformed into the Generalized Method of Moments model as follows: 3) $g d p_{t}=\beta_{0}+\beta_{1}$ Trade $_{t}+\beta_{2} F D I_{t}+\beta_{3} i n f_{t}+\beta_{4} e m p l y_{t}+g d p_{t-1}+\varepsilon_{t}$. Then the moments of the equation are: 4) $E(e i)=0,5) E\left(g d p_{t}-\beta_{0}-\beta_{1} g d p_{t}-\beta_{2} \operatorname{Trade}_{t}-\beta_{3} E D I_{t}-\beta_{4} i n f_{5}-\beta_{3} e m p l l_{t}-\varepsilon_{t}\right)=0$

Data analysis techniques using the GMM method developed by Holtz-Eakin et al. (1998) and Arellano and Bond (1991). The procedure used provides several advantages to the development of panel models that involve bound variables. First, the potential that can cause bias in the estimator is eliminated by eliminating $\mu$ (intruders). Second, the use of instrument variables can produce consistent estimators even though there are endogenous variables in the estimated model. Third, the use of instrument variables allows the existence of consistent estimators, even though there are error variables (Oliveira et al., 2005).

The GMM estimator uses the first difference equation. This transformation will eliminate $\mu$ and allow endogenous variables in the second and previous periods to be the right instrument variables provided there is no serial correlation in random error. It can be tested using the test for serial correlation for residuals in the form of the first difference. An autoregressive distributed lag model can be biased in the first difference estimator as a result of weak instrument variables because there is no close relationship between variables and instrument variables (Blundell and Bond, 1998). A simple way to detect the presence of weak instrument variables is to test the validity of the instrument using the Sargan Specification Test. If the instrument variable used is weak, the parameters generated by GMM-diff will still experience bias.

\section{RESULTS AND DISCUSSION}

The test results using the Generalized Method of Moments analysis method will be explained in Table 2. The results of the analysis using the GMM method show that all variables significantly influence the dynamics of economic growth in Indonesia. This result is proven by the t-statistic probability value, which shows a smaller value compared to the t-table value. Then the value also has a probability of less than $\alpha$. GMM results for trade variables, FDI, inflation, and the number of workers show a significant influence on economic growth, where these results are indicated by probability values less than $\alpha$. Then the estimation results using GMM show a j-statistical value of 0.03 , where the value has a magnitude less than the value of $\alpha=5 \%$. These results prove that the 
instruments used in the model and the model used are valid. Then it is known that the adj-Rsquared value is equal to 0.81 , which results illustrates that all independent variables are able to explain the dependent variable by $81 \%$.

Table 2. Results of the Generalized Method of Moments analysis

\begin{tabular}{lll}
\hline Variable & T-Statistics Coefficient & Probability \\
\hline Trading & $-1,836350$ & $0,0753^{*}$ \\
FDI & 4.091497 & $0,0003^{* * *}$ \\
Inflation & 1,552838 & $0,1300^{*}$ \\
Total Labor & 10,22777 & $0,0000^{* * *}$ \\
\hline Prob J-Statistik & & 0,035058 \\
Adjusted R-squared & & 0,817471 \\
\hline
\end{tabular}

Information:

* Significant $10 \%$

** Significant $5 \%$

$* * *$ Significant $1 \%$

Furthermore, the classic assumption test in this research aims to produce an unbiased linear estimator with minimum variants (Best Linear Unlock Estimator $=$ BLUE) so that there is no unreasonable regression. The stages that must be done is to do some tests, namely the autocorrelation test, normality, and heteroskedasticity. The following will display the results of the classic assumption test diagnosis in Indonesia.

Table 3. Classical Assumption Test Results

\begin{tabular}{llll}
\hline Test Diagnosis & Test & Output Calculate & Probability \\
\hline Autokorelasi & LM Test & 3,940642 & 0,0299 \\
Normalitas & Cholesky & 5,718685 & 0,0579 \\
Heterokedastisitas & White Test & 7,204728 & 0,0299 \\
\hline
\end{tabular}

The results of the classic assumption test presented in Table 3 show that the model used in this study is BLUE. This is based on the fulfillment of several classical assumptions diagnostic requirements, wherein this study there is no autocorrelation between variables, then the data is normally distributed, and there is no heteroskedasticity.

Discussion of the Results of Trade Openness Analysis and Economic Growth in Indonesia. The results of testing using the GMM method note that the variables of trade, FDI, inflation, and the number of workers have a significant effect on economic growth in Indonesia. These results further confirm that the increase in trade will have an impact on economic growth in Indonesia. Empirical findings are consistent with research conducted by Kong, Peng, Ni, Jiang, \& Wang, 2020; Pradhan, Arvin, Hall, \& Norman, 2017; Riekhof, Regnier, \& Quaas, 2019. Some of these empirical findings affirm how the impact of trade openness on economic growth in a country. The conditions are influenced by several economic, social, political conditions that affect the level of openness of a country so that it affects the performance of international trade.

The development of the current conditions of globalization has an impact on increasing the openness of a country's economy that fosters integration between regions of the country; this condition increasingly removes boundaries between countries. This openness has an impact on increasing rapid economic flows between countries in a region such as trade, investment, and in a certain period of time, can increase economic growth. In its development, the level of openness and economic integration that eliminates restrictions in a region of the country also has an impact or a negative risk of spillover from partner countries or other countries that have an impact on economic performance in a country. 
The trade sector in Indonesia is one of the main contributors to economic growth at this time, where the main contributors to economic growth in Indonesia are contributed by the industrial, agricultural, and trade sectors (Statistics Indonesia, 2019). The level of massive trade openness amidst increasingly integrated conditions between countries is expected to be able to support Indonesia's economic growth. However, this openness and economic integration can also create negative risks that can occur if there is economic turmoil. The policy of integration and trade openness and utilization of existing potential sectors are expected to be able to contribute more to economic growth in Indonesia.

Discussion on the Results of Analysis of FDI and Economic Growth in Indonesia. Based on the test results using the GMM method, it is known that the FDI variable has a significant effect on economic growth in Indonesia. This was also emphasized by Abdouli and Hammami, 2016, which stated that international capital flows into the country, especially developing countries as host countries, were able to bring many positive impacts both financial and non-financial. Apart from being a complement to domestic investment, for the host country, FDI will have other positive effects, such as accelerating the transmission of modern technology and developing human capital so that the level of domestic productivity increases and people's needs can be met. This step will clearly accelerate economic growth in terms of GDP. In line with Borenszteina's opinion, Gregorio and Lee (1998) emphasized that the impact of FDI on economic growth depends on the level of human capital. In this case, it is proxied by the level of education, which will further accelerate economic growth. De Mello (1999) also states that a similar positive impact between FDI and economic growth will be felt in developing countries and developed countries both in the short and long term, in the long term economic growth in developing countries will be determined by the abundance of technology and knowledge from countries that make investments, namely developed countries.

FDI is the main prima donna for developing countries like Indonesia. This is, of course, in addition to accelerating the process of transforming economic growth, FDI will make technology and knowledge transfer for developing countries like Indonesia. However, of course, this will be a threat to Indonesia when the flow of foreign capital is not matched by the recruitment process for local workers. The existence of FDI is expected to make a big contribution to the absorption of local labor so that it will not cause other problems, namely unemployment.

Discussion on the Results of Analysis of Inflation and Economic Growth in Indonesia. The results of the inflation analysis using the GMM method show that the inflation variable affects economic growth in Indonesia. This is marked by empirical findings such as those put forward by Aydin, Esen, and Bayrak, 2016 which state that there is an optimal inflation rate or whether there is a threshold in the economic transition where the state carries out an active task in the process of forming a market economy and has fast economic growth affecting price formation in markets with the decisions they make or not. He also stated how the inflation experienced affects the growth rate. The findings obtained provide new evidence of the existence of a non-linear relationship between inflation and economic growth in transitional economies in the long run. In addition, this finding indicates that when inflation occurs above a certain critical value in these countries, inflation will negatively affect economic growth. The predicted critical value is found to be $7.97 \%$ for the transitional economies examined.

Attari, Javed, 2013 stated that there is a long-term relationship between the rate of inflation, economic growth, and government spending, meaning that government spending produces externalities and positive linkages. In the short term, the inflation rate does not affect economic growth, but government spending affects economic growth. The result of the causality test shows that.

There is a unidirectional causality between the inflation rate and economic growth and economic growth with government spending. 
From a study conducted by Mohseni, Jouzaryan. 2016 there is a negative influence between inflation and unemployment on economic growth. Each country has different geographical conditions, so that the optimal inflation target may be country-specific. Policymakers, especially in Asian countries, need to consider the maximum rate of inflation up to a certain threshold as an inflation target to maintain economic stability, thereby increasing economic growth and reducing trade barriers, and motivating investment.

Discussion on the Analysis of the Number of Workers and Economic Growth in Indonesia. The results of GMM for the variable number of workers show a significant effect on economic growth. This is similar to that stated by Ioana, 2014. Increasing the quantity and quality of the number of workers will result in an increase in economic growth. With several programs such as opening new jobs, especially in agriculture, it will actually bring out comparative and competitive advantages in each country based on the agricultural sector. This is believed to further expand economic growth in all lines, not only the industrial sector but to the agricultural and service sectors.

Manpower is a milestone in human resources for realizing economic growth because a productive workforce will contribute to the success of economic growth. Of course, it must be supported by success in the field of education in order to create reliable resources. The problem of imbalance in demand and supply of labor is one of the obstacles for workers. This is due to several factors, namely education, wages, the socio-economic conditions of a country, etc. As an example of the factor of education in Indonesia, workers are required to go through 9 years of compulsory education. This program aims to strengthen workers so that they accelerate the process of economic growth.

\section{CONCLUSION}

This study analyzes the relationship between trade openness and the level of economic growth in Indonesia. The Generalized Method of Moment (GMM) estimation method is used to analyze the relationship between trade openness and economic growth in Indonesia. The estimation results using GMM are known that the trade openness variable significantly influences economic growth in Indonesia, in addition to the control variable that is macroeconomic variables also significantly influence economic growth in Indonesia. These results also provide an overview of the effect of trade openness, which has a positive contribution to the performance of the Indonesian economy, especially on economic growth. The existence of trade openness also presents risks to the performance of the domestic economy as a result of the turmoil that occurs in the foreign economy. The right economic policy in controlling trade openness is expected to reduce these risks and have a positive influence on the Indonesian economy.

\section{REFERENCE}

Arellano, M.\& Bond, S. (1991). Some Tests of Specification for Panel Data: Monte Carlo Evidence and an Application to Employment Equations. Review of Economic Studies, 58(2): 277-297

Arsyad, L. (2010). Ekonomi Pembangunan. Edisi 5. UPP STIM YKPN, Yogyakarta.

Attaria, M. I. J., Javed. A.Y . (2013). Inflation, Economic Growth, and Government Expenditure of Pakistan: 1980-2010. International Conference On Applied Economics (ICOAE). Procedia Economics and Financ. 5. 58 - 67.

Azwar, S. (2001). Metode Penelitian. Pustaka Pelajar Offset : Yogyakarta

Blundell, R., \& Bond, S. (1998). Initial Conditions and Moment Restrictions in Dynamic Panel Data Models. Journal of Econometrics, 87(1),115-143.

Bojanic, A. N., (2012). The impact of financial development and trade on the economic growth of Bolivia. J. Appl. Econ. 15 (1), 51-70. 
Chang, R., L. Kaltani, dan N.V. Loayza. (2009). Openness Can Be Good for Growth: The Role of Policy Complementarities. Journal of Development Economics, 90: 33-49.Arsyad (2010).

Chen, P. dan R. Gupta. (2006). An Investigation of Openness and Economic Growth Using Panel Estimation. Working Paper: 2006-22 November 2006.

Dollar, D. dan A. Kraay. (2001). Trade, Growth, and Poverty. Development Research Group, The World Bank, June 2001.

Esen.O, Bayrak. M. (2016). Inflation and Economic Growth: A Dynamic Panel Threshold Analysis for Turkish Republics in Transition Process. Cell Aydın, Procedia - Social and Behavioral Sciences 229 ( 2016 ) 196 - 205.

Frankel, J.A. dan D. Romer. (1999). Does Trade Cause Growth?. American Economic Review, 89: 379-399. Sachs dan Warner, 1995.

Holtz-Eakin, D., Newey, W., Rosen, H.S., (1988). Estimating vector autoregressions with panel data. Econometrica 56 (6), 1371-1395.

Ioana. D. (2014). Employment - cause and effect of economic growth. 1st International Conference 'Economic Scientific Research - Theoretical, Empirical, and Practical Approaches', ESPERA 2013. Procedia Economics and Finance 8 ( 2014 ) 268 - 274.

Jeffrey D. Sachs, Andrew M. Warner. (1995). Economic Fluctuations and Growth, International Finance and Macroeconomics, Environment and Energy Economics. NBER Working Paper No. 5398 Issued in December 1995.

Kong, Q., Peng, D., Ni, Y., Jiang, X., \& Wang, Z. (2020). Trade openness and Economic Growth Quality of China: Empirical Analysis Using Ardl Model. Finance Research Letters, 101488. https://doi.org/10.1016/j.frl.2020.101488.

Kyophilavong, Phouphet., Shahbaz, Muhammad., Anwar, Sabeen., Masood, Sameen. (2015). The energy-growth nexus in Thailand: Does trade openness boost up energy consumption?. Renewable and Sustainable Energy Reviews 46 (2015)265-274.

Mohseni.M, Jouzaryan.F. (2016). Examining the Effects of Inflation and Unemployment on Economic Growth in Iran (1996-2012) 1st International Conference on Applied Economics and Business, ICAEB 2015. Procedia Economics and Finance 36 ( 2016 ) 381 -389 .

Oliveira et al., (2005). Statistical analysis of cointegration vectors. J. Econ. Dyn. Control 12 (2-3), 231-254.

Pradhan, R. P., Arvin, M. B., Hall, J. H., \& Norman, N. R. (2017). ASEAN economic growth, trade openness, and banking-sector depth: The nexus. Economia, 18(3), 359-379. https://doi.org/10.1016/j.econ.2017.05.002.

Riekhof, M. C., Regnier, E., \& Quaas, M. F. (2019). Economic growth, international trade, and the depletion or conservation of renewable natural resources. Journal of Environmental Economics and Management, 97, 116-133. https://doi.org/10.1016/j.jeem.2018.04.008.

Salvatore, D. (1997). Ekonomi Internasional. Edisi Kelima. Terjemahan. Penerbit Erlangga, Jakarta.

Shahbaz, M., Nasreen, S., Ahmed, K., Hammoudeh, S. (2016). Trade Openness-Carbon Emissions Nexus: The Importance of Turning Points of Trade Openness for Country Panels. Energy Economics.

Vehapi, M. F., Sadiku, L., Petkovski, M. (2015). Empirical Analysis of the Effects of Trade Openness on Economic Growth: An Evidence for Southeast European Countries. Procedia Economics and Finance 19 ( 2015 ) $17-26$.

World Bank. (2018). World Bank Report. Washington: World Bank

Badan Pusat Statistik Indonesia. Statistik Indonesia. 